\title{
Movies Supplement English Classroom to Be Effective in Improving Students' Listening and Speaking Skills- A Review
}

\author{
Hari Babu Thammineni \\ Associate Professor, Department of English, Lendi Institute of Engineering and Technology \\ Jonnada, VSP-VZM Highway Rd, Visakhapatnam \\ hari_theuniversal22@yahoo.com
}

\begin{abstract}
Teaching/learning process of English is always challenging hence its classroom activity should be creative. Since the hue and cry of the day is 'develop your communication skill', the role of English communication is much cited in this era of globalization as an important tool for job prospects, higher education and international business too. So, the English class room is now becoming a workshop of doing various activities for improving the learners' basic communication skills creatively. As a Chinese proverb says: Tell me I forget, show me I remember, involve me I understand, the learner in English classroom today is expected to be involved in practicing communication skills. In such practice, several movie pieces and media clippings are there for ready use to supplement the class room activity in enhancing the above discussed skill set. The natural approach in the class room of this paper presenter is designed to develop basic communication skills involve three stages: Comprehension (preproduction), Early Production and Speech Emergence. This approach to teaching language is believed to be effective particularly to the students having limited English proficiency. In this process, movie pieces and media clippings helped a lot and this paper focuses on how they are used effectively for improving English speaking and listening skills apart from the prescribed syllabus to prepare the students communication skills.
\end{abstract}

\section{INTRODUCTION}

Today's English classroom has gained a great attention to the use of various audiovisual programmes in its teaching/learning process. It is a well-known fact that various audiovisual materials as sources of authentic language input are a great help in stimulating and facilitating the learning of a foreign/second language. Besides, various audiovisual programs have the potential to provide the necessary language input for language learning.

Nunan (1999) highlights the assumption that authentic language input can be extracted from many different sources including TV and radio broadcasts such as news, movies, songs, soap operas, and comedies, recorded conversations, meetings, and newspapers. Gilmore (2007) also defines authentic language input as the language conveying a real message which is produced by a real speaker or writer for a real audience. Similarly, movies prove as potential language inputs to create joyful learning opportunity in language class rooms. The teachers are expected to choose movie pieces or full movies suitable to enhance the learners' proficiency in acquisition of language skills.

Films have many cross-cultural values, provide outstanding basis for the improvement of critical thinking skill, provide a rich source of content for language learners, and offer linguistic diversities. Films also have motivating feature. They facilitate oral communication. Researchers emphasize the use of films in English class room for motivation and learning language skills. Films have the potential to provide exposures to the real language uttered in authentic settings and the culture in which the foreign language is spoken (Stempleski, 1992). Besides, they assist the learners' comprehension by enabling the learners to listen to exchanges and see such visual supports as facial expressions and gestures simultaneously (Allan, 1985; Sheerin, 1982), which may improve their insights into the topic of the conversations.

In the initial attempts of using films in English classroom may have mixed response. However, gradually after each attempt with a focus on selecting which movie would be suitable to the context would give overwhelming response. In providing the task based learning environment, promotion of active viewing of films stimulate the interest of learning language for the students of today's Egeneration. 


\section{IMPROVING ENGLISH WITH MOVIES}

Watching movies is a great way to improve English, especially listening and speaking skills. Films are not usually created for English language learners - they are made for native English speakers. Therefore, the language is exactly how it is heard it in real life - it is spoken quickly, with native accent and pronunciation and using many idioms and colloquial expressions. It is not a good idea to use this as your only method of learning English; it is much more advisable to study at an English school. However, it is recommended to all English language students to watch films in English in their spare time for additional practice.

Choosing a film to watch that is suitable for learner's level of English can be difficult. If learner's level of English is quite low, choosing a movie that one has already seen or a movie made for children that uses simpler language yields good results. However, if learner has a higher level of English, he can try to challenge himself and watch films with more advanced language.

Watching films may tempt the learner to switch on subtitles. It is worth using English subtitles for reading along while listening. Of course, if watching a film in English and reading English subtitles is too difficult, we may have an option of watching films with subtitles in local languages. This is meant to be a fun way to learn English after all but this process must be used only to develop interest to watch the movie. Later he should be prompted to watch movie with English subtitles since the need of watching it is to improve English language skill.

Replaying parts of the film that is not understood by turning subtitles on just for one important scene is always encouraging. It is advisable to watch the film or part of the film first with no subtitles, then with English subtitles and if it is not fully understood, it can be watched at a final time with subtitles in local language. This will help in practice of English listening skills. Today there are many transcripts found for many popular movies, including plot summaries and a list of words and phrases that are not easily understood from the film. Reading them first and watching the film is always a fruitful exercise of language class room.

\section{Watching Movies in ENGLiSh Class RoOM HelP In MANY WaYS}

1. Listening skills: The learners English being used in a very natural way. Some parts may be spoken too fast for the learners to understand but it will be a perfect way for the learner to get used to hearing native speakers talk to each other. We will also hear informal English and slag words and phrases that we often do not find in books or dictionaries.

2. Speaking skills: Hearing natives speak will also help learners speaking skills, especially fluency. We hear how to link words together and where to put intonation on certain words and sentences. Watching films with the peer group and speak about them afterwards or the learners could even find movie scripts online and act out scenes with their friends in language class room shall yield good results in giving opportunity to develop speaking skills.

3. Pronunciation: We all know that English pronunciation is extremely difficult and when we read words it is hard to know how they should be said. Hearing native English speakers' talk to each other will help to hear how words are pronounced. If we are using English subtitles, we will also be able to see how the words are written.

4. Vocabulary: By watching English movies, we hear many new words and phrases, especially idioms and colloquial expressions. Writing down any new words or phrases those are heard while watching movie or remembering them for ready use of them in our conversations is a worthy experience. If we don't understand a few new words, it also gives us an opportunity to refer to the dictionary for the meaning of them.

5. Put knowledge into practice: In English classes we learn a lot of vocabulary and grammar but the learners may not know how to use it in real life. Watching English films will help them understand how to use all the learnt knowledge in everyday situations.

\section{SOME TIPS AND TECHNIQUES}

After investigating the pedagogical value of films and outlining some of the uses of them for effective communication practice in language class room, the following several tips and techniques may help both the teachers and learners of English class room where films or movies are encouraged to have joyful environment in the process of learning language. 
1. Offering students a choice in the film content that is shown in class and selecting the movie based on their interest.

2. Make them ready to respond to the story of the film.

3. Relating the movie for the improvement of LSRW skill

4. Observing the feeling of the learner in watching the movie that is shown

5. Explaining the cultural aspects of the movie

6. Providing extra opportunity to listen to various voice accents

7. Creating interest in getting exposure while watching stories related to politics and science

8. Giving scope to emulating the hero or the other characters of the movie

\section{CONClusion}

With the present day technological advancement, access to the use of various audio visual aids in language class room becomes easier and more joyful. All stakeholders of language learning/teaching process accept today the use of these new inventories for developing creativity of language class room. Use of movies or films in language class also would bring positive impact on the learning process. This exercise may stimulate the imagination of the learner in improving language skills. This paper suggests the learner or teacher of language class room to open new opportunities through movies and films that enhances learning process more joyful with authentic language inputs.

\section{REFERENCES}

Allan, M. (1985). Teaching English with Video. Essex: Longman.

Gilmore, A. (2007). Authentic materials and authenticity in foreign language learning. Lang. Teach. 40: 97-118.

Nunan, D. (1999). Second Language Teaching and Learning. Boston: Heinle and Heinle Publishers.

Sheerin, S. (1982). Exploiting Television Videos with Particular Reference to Teaching ESP. In M.

Geddes \& G. Sturtridge (Eds.), Video in the Language Classroom (pp. 122-133). London: Heinemann Educational Books Ltd.

Stempleski, S. (1992). Teaching Communication Skills with Authentic Video. In S. Stempleski\& P.

Arcario (Eds.), Video in Second Language Teaching: Using, Selecting, and Producing Video for the Classroom (pp. 7-24). Alexandria: Teachers of English to Speakers of Other Languages, Inc. 